\title{
Research on the Effects of China's Solar Photovoltaic Industry Policies*
}

\author{
Jian Yuan \\ School of Economics \\ Central University of Finance and Economics \\ Beijing, China 100081 \\ School of Economics and Management \\ Shenyang Institute of Engineering \\ Shenyang, China
}

\author{
Yuxing An \\ School of Economics and Management \\ Shenyang Institute of Engineering \\ Shenyang, China
}

\begin{abstract}
Solar photovoltaic industry remains an important industry to provide energy supply in the future, and it is of great practical significance and strategic importance for China to facilitate the development of solar photovoltaic industry. At the same time, the supportive policies for solar photovoltaic industry have been introduced by every country in the world, and the Chinese government has issued a large number of industrial policies from the national strategic level, thus promoting the better and faster development of photovoltaic industry. This paper has combed out China's photovoltaic industry policies, and confirmed that the industrial policies have played a role in promoting the investment, industrial employment and technological development of China's photovoltaic industry.
\end{abstract}

Keywords—photovoltaic industry; industrial policy; effects

\section{INTRODUCTION}

In the current big picture of global response to climate warming, it is of great practical significance and strategic importance for the country to promote the development of solar photovoltaic industry. In the early stage of the development of photovoltaic industry, government departments are required to support the development of the industry through credit preferential, subsidies and forced power purchases and other policies, promote the formation of photovoltaic industry chain, and guide the entry of social capital. In the later stage, the continuous development of photovoltaic industry will be promoted by means of the continuous expansion of the production scale of photovoltaic industry and the reduction of photovoltaic power generation cost brought by technological innovation. Therefore, the Chinese government has issued a large number of photovoltaic industry policies from the national strategic level to facilitate the better and faster development of photovoltaic industry.

\section{Current Situation of China’s Photovoltaic INDUSTRY POLICIES}

For the past few years, the rapid development of China's solar photovoltaic industry cannot be scored without the

*Fund: youth program of social science planning fund in Liaoning Province (L15CJY011); youth program of national social science fund (16CJY058); promulgation and implementation of China's photovoltaic industry policies, which provide guidance and support required for the development of photovoltaic enterprises.

In February 2006, the Regulation on Renewable Energy Management issued by the state clearly defined the management and approval methods of the power generation project of renewable energy. This regulation provided guidance directions and implementation standards for enterprises to enter renewable energy power generation after continuing to encourage economic subjects to participate in the exploitation of renewable energy. The Regulation emphasized that power generation enterprises should actively invest in the power generation project of renewable energy, and be able to take the initiative to assume the obligations of the power generation quotas of renewable energy required by relevant national departments.

In November 2007, the government issued the Medium and Long-term Development Plan of Renewable Energy. In order to implement the Renewable Energy Law, reasonably exploit and utilize renewable energy resources, promote energy resources conservation and environmental protection and deal with global climate change, the state formulated the Medium and Long-term Development Plan of Renewable Energy. According to the Plan, by 2010, the annual consumption of renewable energy in China will reach about 270 million tons of standard coal, of which the solar photovoltaic power generation capacity will reach 300 thousand kilowatts; and between 2010 and 2020, the solar photovoltaic power generation capacity in China will reach 1.8 million kilowatts.

In March 2009, the Ministry of Housing and Urban Rural Development and the Ministry of Finance jointly issued the Opinions on the Implementation of accelerating the application of solar photovoltaic buildings. In the opinions, it is emphasized that in order to solve the problem of insufficient application of photovoltaic products in China, the method of demonstration project should be adopted in the early stage of the development of photovoltaic products to facilitate the wide application of photovoltaic products in the field of domestic urban and rural construction. In the same month, the Ministry of Finance also issued the Interim Measures for the Management of Financial Subsidies for the Application of 
Solar Photovoltaic Buildings. The measures explained that there were at present two subsidy models for photovoltaic industry internationally, the first was the United States mode tax credit act, namely, the photovoltaic projects can be able to enjoy $30 \%$ tax credit; the second mode was the German mode, which was to subsidize by means of raising the on-grid price of photovoltaic power generation. In that way, China's "sunroof project" was equivalent to the United States mode, which provided tax credits for China's photovoltaic projects. In addition, the Application Guidelines of Solar Photovoltaic Building Application Demonstration Project in the same year mainly supported the installation of solar photovoltaic building integration. Meanwhile, most of the power generated was applied to projects in building energy consumption.

In July 2009, the Ministry of Finance, together with the National Energy Administration and the Ministry of Science and Technology, issued the notice of C.J. [2009] No. 397, which established the official entry-into-force of the Goldensun Demonstration Project. The central finance will arrange a certain amount of funds to support the demonstration application of photovoltaic power generation technology in other fields and the industrialization of key photovoltaic power generation technologies. The Golden-sun Demonstration Project is a major policy measure following China's photovoltaic construction subsidy policy. The subsidy scope of this round of policy includes large-scale grid-connected photovoltaic power generation projects, photovoltaic power generation projects in areas without electricity and gridconnected photovoltaic power generation projects on the user side. The Golden-sun Demonstration Project is complementary to the photovoltaic construction subsidy policy, which consists of a large number of downstream application fields of photovoltaic industry, thus helping to open up China's photovoltaic market and accelerate the comprehensive development of China's photovoltaic industry. In addition, the Notice on the Excellent Implementation of the "Golden-sun" Demonstration Project emphasizes the acceleration of the implementation of the "Golden-sun" Demonstration Project, and the Notice emphasizes 294 demonstration projects, with the power generation scale of about 642 megawatts ${ }^{1}$, and the annual power generation capacity can reach one billion KWH. The total investment of the project is nearly 20 billion yuan upon calculation.

In August 2011, the National Development and Reform Commission issued the Notice on the on-grid Price Policy for Solar Photovoltaic Power Generation. And the Notice implemented the benchmark on-grid price for non bidding solar photovoltaic power generation projects on a national scale. The fixed on-grid price in the Notice communicated a positive signal, which showed the determination of the state to support the photovoltaic terminal market. Although the detailed rules of fixed on-grid price could not be introduced at that time, it also greatly raised up the confidence of Chinese photovoltaic industrial. It can be said that the promulgation of the Notice on the on-grid Price Policy for Solar Photovoltaic Power Generation has defined the basis for the formulation of solar

Power unit and conversion Gigawatt $1 \mathrm{GW}=1000 \mathrm{MW}$ (megawatt) $1 \mathrm{MW}=1000 \mathrm{KW}$ (kilowatt) photovoltaic policy at the national level and the source of subsidies, which has milestone significance for the exploitation of China's solar photovoltaic application market. The Notice mainly specifies the price of photovoltaic power stations: according to the solar energy resource conditions and construction costs of various regions, the whole country can be divided into three types of solar energy resource areas, and the benchmark on-grid price of photovoltaic power stations is formulated accordingly; the part where the benchmark on-grid price of photovoltaic power stations is higher than the benchmark on grid price of local coal-fired units shall be subsidized through the renewable energy development fund. Price of distributed photovoltaic power generation: the distributed photovoltaic power generation shall implement the policy of full power subsidy, and the price subsidy standard is 0.42 yuan per kilowatt hour, which is paid by renewable energy development fund and transferred by power grid enterprises. Among them, the surplus on-grid electric quantity for selfconsumption of distributed photovoltaic power generation system is purchased by power grid enterprises according to the local benchmark on-grid price of coal-fired units. All kinds of funds and surcharges levied along with the electricity price, and the system reserve capacity charge and other related gridconnected service charges are exempted for the selfconsumption electrical quantity of distributed photovoltaic power generation system.

In August 2013, the National Development and Reform Commission issued the Notice on Exerting Price Leverage to Promote the Healthy Development of Photovoltaic Industry. In order to give full play to the positive role of price leverage in guiding the optimal allocation of resources and promoting the healthy development of photovoltaic power generation industry, it was decided to further improve the price policies of photovoltaic power generation projects in accordance with the relevant requirements of the Several Opinions of the State Council on Promoting the Healthy Development of Photovoltaic Industry (G.F. [2013] No. 24).

In February 2015, the Energy Bureau issued the Letter of Seeking Opinions on the Role of Market in Promoting the Progress of Photovoltaic Technology and Industrial Upgrading. At that time, the progress of China's photovoltaic technology was obviously accelerated, and the market scale was rapidly enlarged, which provided a strong market support for the development of photovoltaic industry. At the same time, there were some problems that some of the backward production capacity cannot be withdrawn from the market in time, the overall technology upgrading of photovoltaic industry was slow, the advanced technology products were short of market support, and there were hidden dangers in the quality of photovoltaic power generation projects. The Letter of Seeking Opinions on the Role of Market in Promoting the Progress of Photovoltaic Technology and Industrial Upgrading focuses on playing the market role of selecting the superior and eliminating the inferior and promoting the photovoltaic technology progress and industrial upgrading.

In 2018 , in order to promote the high-quality development of the photovoltaic industry, encourage the technological progress of the intelligent photovoltaic industry and expand the application, the intelligent photovoltaic pilot demonstration 
work was carried out in accordance with the Action Plan for the Development of Intelligent Photovoltaic Industry (20182020) (MIIT L.D.Z [2018] No. 68) issued by the Ministry of Industry and Information Technology of the People's Republic of China. The plan points out that, by 2020, the construction of intelligent photovoltaic plants will achieve remarkable results, and remarkable progress will be made in the industry automation, the industry informatization and the industry intellectualization; the breakthrough of intelligent manufacturing technology and equipment will be achieved, and the competitiveness of software and equipment supporting intelligent photovoltaic manufacturing will be significantly improved; the supply capacity of intelligent photovoltaic products will be enhanced and the brand effects will be taken shape, and the pace of "going global" will be accelerated. The construction and operation and maintenance level of intelligent photovoltaic system will be improved and applied in many fields on a large scale to form a group of competitive solution suppliers; the development environment of intelligent photovoltaic industry will be constantly optimized, the talent teams are basically established, and the standard system, and testing and certification platform will be constantly perfected.

\section{EFFECTS OF CHINA'S PHOtovoltaic InDUSTRY POLICY}

According to the current situation of China's solar photovoltaic industry policies, this section will focus on the analysis of what effect the implementation of China's solar photovoltaic industry policy has played in the development of photovoltaic industry, and expound from three aspects of industrial investment, industrial employment and technological development.

\section{A. The Influence of Industrial Policies on Investment in Photovoltaic Industry}

According to the actual situation of the development of solar photovoltaic industry, with the continuous introduction of photovoltaic industry policies and the continuous expansion of incentive strength, China's solar photovoltaic industry in previous years has gone through the problems of overheated industrial investment, excess production capacity and the supply of photovoltaic products is greater than the demand. As the photovoltaic industry is listed as the top ten strategic emerging industries, some local government departments begin to focus on the development of photovoltaic industry in order to promote local economic development. At present, there are more than 100 cities in China that are building photovoltaic industry development bases, and some of them have put forward the slogan of building double-one hundred billion photovoltaic bases. The excessive and disordered competition in China's photovoltaic industry leads to the decreasing marginal yield effect of fixed asset investment on the development of photovoltaic industry and also gives rise to serious waste of resources.

\section{B. The Influence of Industrial Policies on the Employment of Photovoltaic Industry}

The implementation of the solar photovoltaic industry policies in China has safeguarded the profits of early Chinese photovoltaic enterprises, which has made a large number of manufacturers in other industries turn into the photovoltaic industry to engage in production and operation and made the employment scale of the solar photovoltaic industry also continue to expand. In the early days, the profits of some links of the solar photovoltaic industry were as high as about $50 \%$, while the profits of Foxconn, a world-renowned large-scale electronic original equipment manufacturer, were only about five points of gross margin. Due to industry returns and support of government departments in solar photovoltaic industry, the China's photovoltaic industry has seen rapid development in the middle and low-end processing and manufacturing links. Solar photovoltaic industry itself remains a capital-intensive industry, but at present, the development focus of China's solar photovoltaic industry is mostly in the middle and low-end of the industrial chain and stays at the middle and low-end processing and manufacturing links of the industrial chain. Although this link can solve a large number of employment problems in China, the following problem is that China's photovoltaic industry generally attaches importance to the scale effects of photovoltaic products in this field and constantly expanding employment and production, therefore, there is a surplus of photovoltaic products produced in this link in China. Therefore, from the long-term perspective of the development of photovoltaic industry, the expansion of middle and low-end employment in China's photovoltaic industry has failed to effectively facilitate China's photovoltaic industry to a higher end of the industrial chain.

\section{The Influence of Industrial Policies on Photovoltaic Industry Technologies}

The key point of photovoltaic industry policies is to support the technology research and development of photovoltaic industry. China's solar photovoltaic industry has gradually developed from the initial filling of market vacancy to the development direction of market segmentation and improving the comprehensive competitiveness of photovoltaic enterprises as the decisive factors. From the perspective of the development of photovoltaic industry, scientific and technological progress is to promote the continuous decline in the price of photovoltaic products, so that the achievements of photovoltaic power generation can be popularized to people's daily life as soon as possible. At present, China's solar cell technology is mainly divided into two major directions. On the one hand, it is the research and development technology of the new generation of crystalline silicon photovoltaic cell, which includes the transformation efficiency innovation of crystalline silicon photovoltaic cell and the technological improvement achievements in the original technology. On the other hand, it is to research a new generation of solar cell technology as evidenced by adopting new materials to replace silicon materials. This kind of technology can promote the conversion efficiency of photovoltaic products and further reduce the cost, so as to form the new photovoltaic products with the characteristics of harmless to the environment and stable power generation. Therefore, the technological progress and innovation of solar photovoltaic industry has an important role in reducing product cost and supporting the future development of solar photovoltaic industry. Although China's solar photovoltaic industry policies provide guidance and support in technology research and development, there is still a certain 
difference between China and developed countries in terms of strength of support for photovoltaic technology research and development. It can be seen that in order to promote the further development of China's solar photovoltaic industry, China's photovoltaic policies need to be continuously improved and replenished at the end of industrial technology research and development.

\section{CONCLUSION}

This paper analyzes the effects of China's photovoltaic industry policies and points out that China's solar photovoltaic industry policies effectively facilitate the rapid development of the photovoltaic industry by means of expounding the current situation of China's photovoltaic industry and industrial policies. The effects of photovoltaic industry policies are reviewed from three different aspects: industrial investment, industrial employment and technological development: in terms of industrial investment and industrial employment, China's solar photovoltaic industry policies all have played an important role, but with the gradual implementation of industrial policies, China's photovoltaic industry has arisen such adverse phenomena as high demand for investment and overcapacity; in terms of technology research and development, the strength of support of China's solar photovoltaic industry policy is a little insufficient, which fails to effectively promote the development of China's photovoltaic industry to a higher field. Therefore, China's solar photovoltaic industry policies still need to be further improved in order to promote the sustainable development of China's photovoltaic industry.

\section{REFERENCES}

[1] Yuan Jian, An Yuxing. Empirical Research on the Influence of Industrial Policies on the Growth of China's New Energy Enterprises [J]. Learning and Exploration 2019 (6) 151-155 (in Chinese)

[2] Dai Hao. Influence Mechanism of Government Subsidies on the Growth of Small and Medium-sized Science and Technology Enterprises [J]. Science and Technology Progress and Countermeasures. 2018, 23 (2): 16-20 (in Chinese)

[3] Yuan Jian. China's Solar Photovoltaic Industry Policy under the Statespace Model [J]. Journal of Shenyang Normal University, 2013 (3): 6568 (in Chinese)

[4] Dusonchet Luigi, Telaretti Enrico. Economic Analysis of Different Supporting Policies for the Production of Electrical Energy by Solar Photovoltaics in Eastern European Union Countries[J].Energy Policy.2010.38(8).4011-4020 